\title{
Economic, Political and Institutional Determinants of Budget Deficits in the European Union
}

\author{
ALI BAYAR \\ BRAM SMEETS \\ CESIFO WORKING PAPER NO. 2611 \\ CAtegory 6: Fiscal Policy, Macroeconomics and Growth \\ APRIL 2009
An electronic version of the paper may be downloaded
- from the SSRN website:
- from the RePEc website:
www.SSRN.com
www.RePEc.org
www.CESifo-group.org/wp \\ - from the CESifo website:
}




\title{
Economic, Political and Institutional Determinants of Budget Deficits in the European Union
}

\begin{abstract}
Using an extended data set of EU countries ranging from 1971-2006 and relevant econometric methods, we investigate the economic, political, and institutional determinants of government deficits in the EU. The results show a strong opportunistic behaviour of policymakers which leads to political business cycles. We find that political fragmentation does not play a significant role in government deficits. Partisan behaviour has a weak effect. The stability of the government has a significant negative impact on the size of the budget deficit. The paper also shows the significant effects of the Maastricht Treaty on fiscal consolidation.
\end{abstract}

JEL Code: C33, E62, H6, H87.

Keywords: fiscal policy, European Monetary Union.

Ali Bayar

Free University of Brussels

EcoMod

Avenue F.D. Roosevelt, 50

C.P. 140

Belgium - 1050 Brussels

Ali.Bayar@EcoMod.net
Bram Smeets

EcoMod

Belgium - Brussels

bram.smeets@ecomod.net 


\section{Introduction}

The extent of government deficits and debt has been one of the most debated issues in economics in recent years. Whereas budget deficits were initially considered to be a merely macroeconomic phenomenon, starting from the 1980s a new field in Political Economics developed, casting light on the topic from both economic and political perspectives. This movement was inspired in particular by the notion that many industrialised countries had been facing considerable budget deficits following the first oil crisis in 1973. However, whereas existing economic theory would predict these deficits to vanish during more prosperous times, in most countries they were persistent over the following decades. As a consequence, debt levels had been increasing steadily over the same period and besides, the deficits and debt levels varied in size among various countries facing similar economic shocks. In order to explain the cross-country differences among the OECD-members, the existing, normative economic theory alone did not suffice. Therefore, political variables, such as the ideological characteristics or the degree of fragmentation of the government, and institutional factors, like certain aspects of the process of budget determination, were included as additional explanatory variables in models that tried to give a positive explanation for the observed patterns in deficits.

At the same time, in Europe the process of integration towards an economic and monetary union took shape, and with the ratification of the Maastricht Treaty, signed by the 15 members of the EU in 1992, the participating governments bound themselves to strict guidelines on their macroeconomic policy measures. In order to evaluate the sensibility of the particular measures imposed, an extensive literature developed, both preceding the agreement, when the contents were still negotiable, and afterwards, evaluating the outcomes and consequences. Almost simultaneously, in the US the Balanced Budget Rule was introduced, that imposed budgetary requirements as well and caused a discussion on the effectiveness of fiscal constraints.

The quest for models explaining budget deficits from a positive perspective considerably gathered momentum over the last two decades, and debates on the issue of aging populations throughout the western world called for a further increase in 
attention for the determinants and consequences of deficits on the one hand or successful fiscal policies on the other. The literature on this topic can be categorised in various ways, e.g. according to the particular variables whose explanatory power is considered, with main emphasis on politically oriented variables - political stability, size of government, fragmentation of government - vs. institutional factors - type of budgetary procedures, negotiation power of unions etc. Second, a considerable number of contributions deal with the question whether political business cycles are present in the series of budget deficits. Besides, various regions have been under consideration, ranging from the EU or a selection of OECD countries to the developing world. For the former region, the impacts of the Maastricht Treaty and the Stability and Growth Pact on economic and budgetary performance have been analysed.

A natural alternative criterion for categorisation of the literature would be the employed methodology. However, it is surprising to note that, in this respect, the existing works do not differ significantly from each other, to the extent that the vast majority of the literature analyses panel data consisting of pooled, country-specific time series, and uses simple Ordinary Least Squares (OLS) to estimate these models. ${ }^{1}$ Especially when focusing on the EU, with a high degree of interaction and interdependence between economies, a closer consideration of the validity of the assumptions underlying this rather general method seems appropriate, but has been provided in barely any contribution. Starting from such an analysis, and consequently developing an appropriate methodology, it will be interesting to evaluate whether, next to differences regarding the set of countries or the time period under consideration and the choice or specification of explanatory variables, the estimation method can also be added to the list of causes that explain the differences in results that exist between various studies in the field.

\footnotetext{
${ }^{1}$ Methodological differences have been considered concerning the definition of particular explanatory variables has received considerable attention (see e.g. Roubini and Sachs (1989) and De Haan and Sturm (1994)
} 
This paper will focus on the 15 countries in the EU that signed the Maastricht Treaty, and uses data ranging over the period 1971-2006 to analyse the economic and political determinants of budget deficits and the development of their impacts over time. First it will present a thorough investigation of the data, considering the different dimensions of the dataset. In line with the outcomes of the respective (econometric) tests, a cross-sectional time series model will be specified and estimated. This model is used to evaluate the explanatory power of various variables that are selected in line with earlier findings in the literature, and as well to update these results using new data available. Besides we analyse the presence of political business cycles in the path of budget deficits. As an addition, the structural impacts of the ratification of the Maastricht Treaty and the imposition of the Stability and Growth Pact will be evaluated. Finally, the last section concludes our findings.

\section{Literature review}

The basic 'equilibrium' model proposed by Barro (1979) and Lucas and Stokey (1983) argues that in order to minimize distortions, tax rates should be relatively constant over time and therefore spending and revenue shocks should be smoothed by budget deficits and surpluses. However, this normative economic argumentation of the 'tax-smoothing' model does not explain why the budget deficits that emerged following the oil crises in the 1970s persisted, and neither why countries facing similar economic shocks experienced very different paths of budget deficits. Alesina and Perotti (1995 and 1996) argue that economic theory alone cannot explain the issue and when attempting to find positive explanations for the path of budget deficits, instead of normative prescriptions, one should therefore address the political and institutional aspects of the question. Various variables exist that are candidates to be included in such a model.

In a seminal work, Roubini and Sachs (1989) consider the relation between deficits and the structure of the governments and in particular its fragmentation, finding that multiparty coalition governments have a higher tendency to develop large and persistent deficits. Besides, countries where governments have short tenures tend to have higher deficits on average. In a re-examination of these results, Edin and 
Ohlsson (1994) reveal the sensitivity of the former conclusion to the definition and dimension of the variable capturing government fragmentation, claiming that only minority governments have a particular tendency to develop large deficits, and differences between majority governments with different numbers of participating parties are insignificant. De Haan and Sturm (1994) found support for neither of the two hypotheses based on an investigation of the countries in the European Community in the $1980 \mathrm{~s}$, and conclude that there are no significant differences in explanatory power among single party majority governments, coalition governments and minority governments. In more recent literature, different definitions of the degree of fragmentation are considered and e.g. Volkerink and De Haan (2001) find that the number of spending ministers has stronger and more robust explanatory power than the number of parties in the government. Perotti and Kontopoulos (2002) find supportive results and show that the latter variable even turns insignificant.

Parallel to the discussion on political relations and their impact, a large part of the literature on deficits has focused on finding models that explained the behaviour of policy-makers by considering differences in ideological characteristics or by interpreting deficits as a strategic mean that can be used when seeking re-election. In this context, Franzese (2002) gives a comprehensive overview of existing views, distinguishing between two types of models that are generally used to explain and interpret the behaviour of politicians. Opportunistic models argue that policy is determined by electoral motivations: Politicians have no preferences of their own, based on a political conviction, but just follow policies which maximise their probability of winning the next elections. Political cycles depending on these policies typically show higher deficits in election years or shortly before, as a result of the government giving bonuses to the electorate and trying to gain popularity right before the elections. In an empirical investigation of this question, Mink \& De Haan (2005) find that during election years deficits tend to be higher, whereas in the year preceding the elections they are not. On the other hand, Andrikopoulos et al. (2004) focus on a larger time period and find that instead right-wing governments tend to be in favour of fiscal stabilisation during election times. 
Partisan models on the other hand emphasise policymakers' ideological motivations and argue that right- and left-wing parties follow different policies, at least partially determined by their ideological preferences. Related cycles should show different patterns in deficits depending on the ideological orientation of the government in office. Alesina and Roubini (1997) find no significantly higher deficits for left-wing governments as compared to other governments. Perotti and Kontopoulos (2002) show that ideology only influences the budget process via expenditures - transfers in particular -, and find no significant evidence that it leads to differences in surpluses or deficits. Volkerink and De Haan (2001) use an ideology index and find similar results. Mulas-Granados (2003) analyses the influence of political variables on the decomposition of the government budget, and finds that left wing governments are not directly associated with higher or lower deficits, but do manage to have more successful fiscal adjustments in the second half of the 1990s.

Since the early 1990s, several institutional and political changes have limited the freedom of the European national governments (and US state governments) to pursue a discretionary budgetary policy. Being subject to strict rules and guidelines imposed by the ratification of the Maastricht Treaty, the implementation of the Stability and Growth Pact and the introduction of the Euro, many countries managed to escape from the persistent and massive deficits that had been common during the past decades. Nevertheless, the sensibility and appropriateness of these measures has been subject to a broad debate. Buiter et al. (1993) and Roubini (1995) examine the relevance of fiscal constraints and claim that rigid fiscal rules deprive the policy maker of an important tool to stabilize output and smooth tax distortions over time. Ballabriga and Martinez-Mongay (2005) evaluate the sustainability of public finances in a country set including the EU, both before and after 'Maastricht'. They find that the majority of the member states in the EU pursued sustainable fiscal policies both before and after the enforcement of the Maastricht-criteria and consequently question the necessity of the rigid rules of the SGP.

When performing empirical analyses in political economics, one usually deals with repeated (yearly) observations, for a fixed number of countries. The dimensions of 
these datasets differ from the typical panel data set most commonly used in microeconomic studies, in that the number of years under consideration is large and the number of countries relatively small. As Beck and Katz (1995) point out, applying standard regression techniques such as OLS or GLS on these cross-sectional timeseries models comes with serious flaws, and leads to an overestimation of the significance of the explanatory variables in the model. Especially given the contradictory results concerning the explanatory power of some of the variables that have received most attention in the literature, it is important to use appropriate techniques that lead to a realistic estimation of the parameter values and their variation. However, the vast majority of the studies straightforwardly apply standard OLS, without evaluating the validity of the assumptions underlying the use of this technique. In this paper we will carefully address these issues and select a corrected estimation method based on Beck and Katz (1995) that is more in line with the structure of our dataset and the observed patterns in the particular time series.

\section{Empirical Model Specification}

Before turning to an analysis of the dataset used for our analysis, this section presents the specification of the time-series cross-section regressions that are used as a modelling framework for our analyses throughout this paper. The baseline model is similar to the models used in the major part of the existing relevant literature (see e.g. Roubini and Sachs (1989) and Alesina and Roubini (1997)) $)^{2}$, starting from a basic economic model that is extended by including political and institutional variables:

$$
D B Y_{i, t}=\alpha_{0}+\alpha_{1} D B Y_{i, t-1}+\alpha_{2} \Delta U B_{i, t}+\alpha_{3} \Delta y_{i, t}+\alpha_{4} D R B_{i, t}+\sum_{j} \alpha_{j} P I_{j, i, t}+v_{i, t}
$$

Equation (1) defines a pooled cross-sectional time series model, where $D B Y_{t}$ is the deficit-to-GDP ratio, $\Delta U B_{t}$ is the change in the unemployment rate, $\Delta \gamma_{t}$ is the change in the GDP growth rate, $D R B_{t}$ is the change in real debt-servicing costs, and $P I_{i}$ are

\footnotetext{
${ }^{2}$ Other authors choose a specification with the change in deficits as dependent variable, but due to the presence of the lagged deficit as explanatory variable, this does not influence the parameters found for the other explanatory variables.
} 
various political and institutional variables. Finally, $v_{i, t}$ denotes the error term that may be composed of various country- or time-specific components depending on specification tests that will be carried out in the next section.

The deficit-to-GDP ratio is computed as the ratio between net lending including interest and the current GDP. DRB is defined as

$$
D R B_{i, t}=\Delta\left(r_{i, t}-\pi_{i, t}-g_{i, t}\right)\left(D e b t_{i, t-1} / G D P_{i, t-1}\right)
$$

where $\Delta$ denotes the first difference operator, $r$ is the long-term nominal interest rate, $\pi$ is the inflation rate, $g$ is the real GDP growth rate, and the term on the right is the government debt-to-GDP ratio, lagged by one year.

In $P I_{i}$ various political and institutional variables are considered:

- POL captures the degree of government fragmentation. Following the approach by Roubini and Sachs (1989) it takes the value of 0 for one-party majority governments, 1 for coalition governments with two parties, 2 for coalition governments with three or more parties, and finally 3 for minority or care-taking governments. The index is first established on a monthly basis and then transformed into the annual index through a weighted average. We test for the impact of the index as a whole and also for effects of the respective categories by introducing dummy variables in the regressions (POL0, POL1 and POL2, the reference is POL3).

- IDEO represents the ideological complexion of the government. Following the methodology established by Woldendorp, Keman, and Budge (1998) it attempts to account for the relative strength of parties in government with reference to the left-right dimension, through a five-point scale in which the proportional shares of the left, center and right are transformed into scores (1 to 5) representing the degree of dominance of either party both in parliament and government. It takes the value 1 for right-wing governments, 2 for rightcentre governments, 3 for a balanced situation, 4 for left-centre governments, and 5 for left-wing governments. The index is first compiled on a monthly basis and then transformed into an annual index as a weighted average of the 
monthly values. The index is introduced in the regressions as a single variable and also, alternatively, in the form of dummy variables (IDEO1, IDEO2, IDEO3, IDEO4, and IDEO5, where we take as reference the balanced situation represented by IDEO3). As main source for the index we use Woldendorp, Keman and Budge (1998), although we made adaptations according to our own judgement - based on historical data - and updated the index to cover the entire period 1971-2006. ${ }^{3}$

- ELEC_YR is a dummy variable taking on value 1 in years during which a country had (one or more) parliamentary elections and 0 otherwise.

- DUR is the duration of the government (in hundreds of days) that holds office in a particular year. In case there was a change of government, the variable is computed on a monthly basis, and the weighted average over the year is reported in DUR.

- STAB is a stability index, computed as the ratio of the actual duration of a government that held office in a particular year (as measured in the variable DUR) and the maximum number of office days that the government could reach, as determined by the constitution of every country (e.g. 1460 for Germany, 1825 for France)

All variables are time-variant and they allow us to test for several of the effects analysed in previous studies. POL can be used to test the supposed association between fragmented government and higher deficits. In order to make a distinction between opportunistic and partisan behaviour of governments, we will use the variables IDEO, CHANG and ELEC_YR as criteria. Finally, DUR and STAB allow for an investigation of the effects of stability (and particularly instability) on budget deficits.

\section{Economic and Political Data: Stylised facts and econometric tests}

\footnotetext{
${ }^{3}$ The updated index is available from the authors upon request. Summary statistics are presented in section 4.
} 
This section will present summary statistics on the main variables in our dataset and besides presents the results of econometric tests used to select the most appropriate testing method and to ascertain the absence of disturbing factors in the estimation, such as unit roots and autocorrelation. Columns 2-5 of table (1) show the average values of the public balance per country, where we divided the sample period in decades and besides in a pre- and post-Maastricht era. ${ }^{4}$ Note that in this table, the budget balance as difference between revenues and expenditures is presented, with a positive value corresponding to a budget surplus, whereas our dependent variable in the regression analyses will be the budget deficit. The figures in table 1 clearly exhibit that almost all countries faced considerable and persistent budget deficits during the first two decades under consideration.

$<<<$ Insert table 1 about here. $>>>$

During the 1970s and the 1980s, only Luxembourg and the UK were able to improve between the decades; Luxembourg even managed to have budget surpluses in 17 years out of the first 20 years under consideration in our sample, while the UK still faced deficits in 17 years over the two first decades, but managed to cut back their deficits in the six consecutive years after 1984, and switch to a surplus at the end of that period. Belgium and Italy faced the highest and most persistent deficits, having values well over five percent in at least 19 consecutive years after 1974. Ireland also experienced deficits in all years, with slightly lower levels on average, whereas Greece did particularly badly during the 1980s, with values exceeding the 10 percent in the second half. The Scandinavian countries were an exception concerning their budgetary policies, since they managed to control their deficits after the deterioration in the second half of the 1970s, and they were able to present sharp improvements after 1982, leading to surpluses by the time of 1986. Whereas Sweden and Denmark did experience deficits of up to seven percent in the period in between, Finland even outperformed them by only having surpluses in the first two decades. The remaining

\footnotetext{
${ }^{4}$ We assume that the post-Maastricht era started in 1994, reasoning that the treaty admittedly went into force slightly earlier, on 1 November 1993, but its effects on the macro economies are likely to become present during the first year following its ratification. Besides, as of this year the convergence criteria applied.
} 
European countries did not manage to pursue this anti-cyclical policy with deficits as smoothing instrument and faced persistent deficits after 1974. Spain and the Netherlands faced deterioration after 1973, reaching deficit levels well over six percent in the early 1980s, and were stuck to values that were just slightly smaller afterwards. Austria experienced a comparable development, although its peak was smaller, just over four percent, whereas Portugal went through worse times and faced deficits ranging between four and 9,4 percent after 1974. Finally, Germany and France succeeded to keep their deficits under three percent in most years, although Germany did not experience any years with budget surpluses between 1974 and 1988, and France experienced just two years with very small surpluses over the period from 1974 until today.

This latter observation makes France rather exceptional: whereas all countries started to pursue policies of fiscal consolidation to improve their budgetary situations, particularly after 1993, the year in which the Maastricht Treaty was ratified, this led most of them to a state of budget surpluses, except for France, Spain, Portugal and Italy. The countries that did manage to switch their deficits into surpluses experienced a peak in their budgetary situation in 2000 or 2001, and saw a decrease following the economic deterioration in the early 2000 s.

In the first part of its empirical section, this paper will address the effect of the degree of fragmentation of the government on budget deficits. Table 2 presents summary statistics for the index that we use to categorise the governments that the respective countries face every year, as explained in the previous section. Except for France, Portugal and The Netherlands, all countries have a strongly dominant degree of fragmentation, to the extent that they spend at least two thirds of the time period under consideration in a specific category. This often reflects the division of power or simply the numbers of parties - in parliament; the UK and Greece usually have single party-governments, whereas Belgium and Finland typically are lead by broad coalitions. Denmark and Sweden often have minority governments, whereas Germany and Luxembourg have always been led by a coalition of two parties. 
$<<<$ Insert table 2 about here. $>>>$

Next to the impact of political fragmentation, this paper will focus on the correlation between the extent of budget deficits and the ideological convictions represented in the government. Table 3 presents an overview of the proportion of time spent in every ideological category, where category 1 corresponds to a right-wing government, and category 5 to a left wing-government, as explained in the previous section. Luxembourg, outperforming all other countries by almost solely experiencing surpluses rather than deficits, had no left wing or centre-left governments, but spent most of the years under consideration having neutral governments. This also holds for Finland, the other country that spent most of the time during last decades in a situation of budgetary surplus. It did not have any government that was either purely left-, or solely right-wing, and spent more than 27 years with neutral governments. However, the suggestion that apparently countries that spent the biggest fraction of our sample period under neutral governments can be associated with prosperous fiscal policies, is contradicted by the notion that also Belgium fits in this category. Figure 1 gives a graphical, yearly representation of the path of deficits.

If the share of time that each country spent under a certain ideology showed a high concentration in one particular category for each country, the degree of correlation with country-specific dummy variables, covering fixed effects, would be high. However, this is not a problem in our case, since both between and within the countries one can observe a considerable variation over the categories. A more important point of attention is the fact that several countries either experienced dictatorship during a considerable part of our sample period, like Spain and Portugal, or faced great political instability during a long proportion of the time or some specific periods. Intuitively, one would expect these characteristics to respectively exaggerate or diminish the effect of ideologies, due to the political power that the government possesses, or the lack thereof. Particularly in relation to the budgetary policy, dictatorships can be expected to have strong dominance, whereas governments during politically instable times, having a short lifetime or expected lifetime, will be mostly concerned with short-run (reparation) measures rather than with pursuing a 
long-run policy based on their ideological conviction. The relevance of these factors should therefore also be considered, next to the analysis of links between ideology and deficits.

$<<<$ Insert table 3 about here. $>>>$

Table 4 shows the average values of the stability index, as a fraction of the actual government duration and its maximum lifetime. The EU average shows a gradual increase in stability over time, and when comparing the countries one can observe that Luxembourg is the only country where the government on average fulfils more than 90 percent of its term. On the other hand, Italy is the country that experienced the greatest political instability, with in total 36 government changes. Before 2000, the country only faced two years during which the index exceeded the value of 50 percent. One should note here that the results for the last time period, 2001-2006 can be somewhat biased due to right-censoring: we use December 31, 2006 as end date of our sample, and durations of the latest governments are calculated up until this date.

$<<<$ Insert table 4 about here. $>>>$

\subsection{Econometric tests and Estimation Method}

As is common in most applications in political economics, the panel data that we use in our analyses attain the particular structure of cross-sectional time series: the number of years (time points) under consideration is relatively large and the number of countries (units) under consideration is particularly small, in comparison with typical panel data models. Although this characteristic does not change the structure of our dataset, that is still constructed by pooling the country-specific time series, Beck and Katz (1995) show that it does have important consequences for the estimation errors, that are likely to exhibit patterns that violate the basic assumptions of OLS estimation. In an OLS framework, the Gauss-Markov assumption namely states that errors should be generated spherically, requiring that they are 
independently and identically distributed (i.i.d.) over all observations. ${ }^{5}$ However, particularly in the models on budget deficits that we consider, there are several possible challenges to this assumption.

In order to be identically distributed over all NT observations, the error terms should be both independent between countries and independent within one country over time. Two conditions could violate this assumption: contemporaneous spatial correlation and serial correlation. Especially the former effect is likely to be present in our data, since it seems reasonable to expect that the strong links between European economies will cause the performance of our model to be correlated between the different countries: if in year $t^{*}$ the model yields a high error for Germany, then the error for The Netherlands can be expected to be high too. When applying OLS to our economic baseline model $^{6}$, we find that the correlation between the errors of the specific countries can amount up to 0.60 (Germany and Luxembourg). Considering the second potential violation of the assumption of identicalness, one could reason that a poor performance of our model in country $i$ in year $t$ is likely to show persistence over time. In order to draw inference on the importance of this effect, we apply a Lagrange multiplier test on the residuals of the OLS regression for the baseline model (c.f. Wooldridge, 2002). Based on this test, we can not reject the null hypothesis of no serial correlation in the errors. ${ }^{7}$ Main explanation for our finding that serial correlation is not clearly present is the inclusion of a lagged dependent variable in our model. Although that prevents us from the problems that autocorrelation in the residuals would bring along, it also raises the question whether the dynamics in the underlying series are modelled properly in this manner, or whether the data under consideration contain a unit root.

\footnotetext{
${ }^{5}$ In matrix notation: $\Sigma=\sigma^{2} \times I_{N T}$, where $\Sigma$ is the variance-covariance matrix, $I_{N T}$ is the $N T x N T$ identity matrix and $\sigma^{2}$ the error variance.

${ }^{6}$ Model specification: $D B Y_{i, t}=\alpha_{0}+\alpha_{1} D B Y_{i, t-1}+\alpha_{2} \Delta U B_{i, t}+\alpha_{3} \Delta y_{i, t}+\alpha_{4} D R B_{i, t}+v_{i, t}$

${ }^{7}$ The statistic $N T \cdot R^{2}=2,354$, with the appropriate critical value $3,825\left(\chi^{2}(1)\right)$.
} 
For some countries, the individual paths of the budget deficits show patterns that lead to the conclusion that a unit root is present in the data when performing the standard stationarity tests. Although the theoretical long-run implications - e.g. concerning the sustainability of public finances - of such a result would pose additional and interesting challenges to the exercise of modelling the dynamics of the individual series, we do not need to go there in the current context, since we are concerned with estimating a pooled model for the 15 countries. Therefore, the appropriate stationarity test should be based on the entire dataset. One of the several available tests is suggested by Im, Pesaran and Shin (2003) and is based on an average of the individual Dickey-Fuller test statistics. Using this test, we can reject the null of a unit root. $^{8}$ Therefore, we draw the conclusion that the major challenge to the assumption that errors are independently distributed comes from spatial dependencies among the countries rather then temporal correlation or issues concerning the dynamics of our model.

The second assumption that OLS poses is that errors are identically distributed. This rules out heteroscedasticity and requires that for all countries, the errors have the same variance. Performing a White test on our baseline model, we find convincing evidence for heteroscedasticity.

Based on the analyses above, we conclude that the major challenges to the GaussMarkov assumptions come from the spatial characteristics of our dataset, and relations and differences between the countries in our panel should be incorporated in the model. Beck and Katz (1995) show that a standard method to take contemporaneous correlation into account, Feasible Least Squares based on Parks (1967), leads to inefficient estimators as well, and in particular it underestimates the variance of the estimates, such that inference will typically be biased towards significance of the variables. Therefore, they suggest a sensible adaptation to OLS estimation that would allow for these desired subtleties in the estimation of the covariance matrix, while still leading to accurate estimates. In our empirical analyses, we will employ this estimator, which they call Panel Corrected Standard Errors

\footnotetext{
${ }^{8}$ Detailed test results are available from the authors upon request.
} 
(PCSE), in order to find accurate parameter estimates of the significance of the explanatory variables under consideration.

The algebra that is used for calculation of the PCSE estimator is described in the appendix. However, we should note here that, although the contribution made by Beck and Katz (1995) is heavily cited and the PCSE estimator frequently used in other fields of political economy, it is not necessarily the optimal estimation approach for TSCS models. The gains in accuracy, as compared to e.g. the Parks' method, are dependent on the particular characteristics of the data, and using OLS with corrected errors still leaves the possibility of other problems that may cause a considerable bias in the estimation of either the parameters or the related variance for inference. As Adolph, Butler and Wilson (2005) point out, particularly unit heterogeneity and the specification of dynamics are critical issues when dealing with TSCS. The debate on the pros and cons of the PCSE estimator is quite recent and has not led to a univocal conclusion on the optimal estimation method for TSCS data. This lack of consensus is in line with ongoing debates on e.g. panel unit root tests, or on the extent to which one allows for heterogeneity in the parameters of a panel data model. Accordingly, and for TSCS models in particular, the most appropriate estimation method depends on specific characteristics of the data.

Based on the econometric results presented above, we consider the PCSE estimation method the best available option to take the country-specific characteristics and interdependencies in the error term into consideration. In addition to allowing for heterogeneity and spatial dependence between the countries, we also include fixed effects in almost all models presented in the empirical section of this paper, based on tests on the significance of the corresponding country-dummies used to model the unobserved heterogeneity. Besides, we include a lagged dependent variable in our model, with a lag length of one year. This inclusion is based on evaluation of a standard criterion for the lag length - the Schwarz criterion - and since this choice is in line with the model specifications chosen in almost all existing literature on budget deficits, it facilitates a comparison of existing results with ours, based on a more appropriate estimation method. 


\section{Empirical Results}

The first column of table 5 presents the estimation results of the baseline model. This regression only includes economic variables, and serves as a benchmark for the more extended analyses that will follow. The autoregressive component in the model is highly significant, with a positive persistence coefficient that is close to 0,9 . The change in unemployment is significantly correlated with deficits mainly because an increase in unemployment leads to an increase in government expenditures. Real debt servicing costs have a positive coefficient because an increase in the real interest rate directly leads to higher deficits. However, the t-ratio, indicated between brackets and calculated using the estimated standard errors based on PCSE, reveals that this effect is insignificant. Finally, economic acceleration yields to an increase in revenues through taxes, and hence to a decrease in the deficit. By using the PCSE method, we implicitly allow for country-heterogeneity in the variance of the error term.

$<<<$ Insert table 5 about here. $>>>$

In order to allow for heterogeneity in the level of the error term as well, in column 2 of table 5 the same baseline equation is estimated, but this time including countryspecific dummy variables that cover the fixed effects. The F-test on these dummy variables, which is displayed in the last row of table 5, shows that we can reject the null of overall insignificance. The inclusion of fixed effects in the model does not lead to considerable changes in parameter values. Two differences with the initial, more homogeneous model are interesting to observe: The persistence of the lagged dependent variable slightly decreases, and hence its parameter value moves further away from a unit root value to around 0,83. Apparently, the fixed effects represent differences in the mean deficits between countries - i.e. spatial effects over the entire sample period - that were initially captured by a higher estimate of persistence of the dependent variable - i.e. temporal effects that capture these cross-country differences. Besides, adding fixed effects to the model yields an increase in the t-statistic for the change in debt-servicing costs, although the variable remains insignificant. However, an important note is that the standard t-statistic, obtained by applying simple OLS, 
reports a value of 2,027 and hence one would draw the reverse conclusion when using the traditional inference methods. Still, excluding the variable from our model does not influence the parameter values of the other explanatory variables, and in order to better facilitate a comparison with existing literature, in which the variable is regularly included, we decide to leave it in our model.

A first analysis of the time series of budget deficits showed that the European countries started to pursue policies of fiscal consolidation or at least improved their budgetary situation in the early 1990s. These developments evolved in a period during which countries were bound to stricter measures and budget rules that were introduced in the Maastricht Treaty and would later become even more rigid in the Stability and Growth Pact and upon entrance to the European Monetary Union. Although it would be very interesting to differentiate between these different occasions and their corresponding effect on the budget outcomes, it appears that the 'Maastricht-effect' is the strongest of the three and besides the other effects are insignificant when included in a model together with the Maastricht-dummy. ${ }^{9}$ The third equation in table 4 builds on the baseline model, and presents an extension by adding this temporal dummy variable that covers the change in the deficit level following the enforcement of the Maastricht Treaty; it takes the value of 1 starting in 1994 and all years afterwards, in correspondence with the argumentation we explored in the data section. When allowing for different starting years for our dummy, indeed we find that the Maastricht effect appears to be stronger starting in 1994 than with starting dates in the surrounding years, both in terms of magnitude and significance. ${ }^{10}$

The results show that the new rules and regulations as agreed upon in Maastricht lead to deficits that are lower by more than 0,5 percent of GDP. Given the important influence of this institutional change and the fact that it applies to all countries,

\footnotetext{
${ }^{9}$ These results are not presented in the table, but are available from the authors upon request.

${ }^{10}$ Some other studies choose a different starting point for the Maastricht effect; e.g. Busemeyer (2004) chooses 1992. In correspondence with our results, he finds that the fiscal performance of the participating countries indeed improved afterwards.
} 
irrespective of the other political variables that will be considered later in our analyses - e.g. ideology, fragmentation or the timing of elections -, we will include the Maastricht dummy in our baseline model that will be used as a starting point for the more extended models.

\subsection{Political Fragmentation}

The variable that has gained most attention in the literature over the last decades as potential determinant of budget deficits is the political fragmentation of the government. If any conclusion can be drawn from this debate, it is that the estimated effect is highly dependent on the specification of the variable and the judgements concerning the particular categorisation of the respective countries over time. Table 6 presents results of regressions based on a model extended by our own definition of the index variable on political fragmentation, as exposed and summarised in the data section earlier in this paper. In the first column, the regular index, ranging between 0 and 3, is employed as explanatory variable, whereas in the second column, dummy variables are used to identify the effect per category. From both columns we can conclude that, whereas effects of the economic variables in the baseline part of the equation are similar to findings presented before, fragmentation does not play a significant role. This is in line with the conclusions from existing literature, in particular given that our criteria for categorisation are closest to those employed in Edin and Ohlsson (1994), who reach the same conclusion.

At the same time our data set covers a considerably longer period than most existing studies, which allows us to additionally evaluate whether the impact of fragmentation on deficits changes over time. The panel at the right of table 6 provides more insights on this issue, reporting results for rolling window regressions on subsamples of 20 years. Since PCSE estimation uses estimates of bilateral covariances between all pairs of country-specific error terms, there is a trade-off between reducing the number of years, for evaluation of temporal patterns, and the accuracy of the estimation procedure. For this reason, we decide to evaluate patterns over time by analysing 20 year-periods; further reduction of the sample period prove not to lead to more informative results, but does bring along a loss in estimation accuracy of the 
correlation coefficients, that would be based on a limited number of observations. Indeed, when decreasing the length of the subsample further, we observe an increase in the variability of the correlation estimates over the different samples that can be attributed to the limited number of observations underlying these estimates. Therefore, we only present results for subsamples of 20 years.

In the period 1972-1991, the index exhibits significant explanatory power at a 10 percent level. The negative sign of the variable is mainly due to the lower parameter value for category 2, as compared to the first categories 0 and 1 . However, neither of these effects is significant. In the latter two subsamples, the fragmentation index switches sign, but again the significance of both parameters is very weak. Overall, the political fragmentation variable that we exploit in our analyses appears insignificant, and in the only subsample where we do find a relation with our dependent variable, 1972-1991, we cannot attribute this finding to significant changes in the relations with underlying categories. These conclusions add to the robustness of our negative results, and do not change when the length of the subsamples is further reduced.

$<<<$ Insert table 6 about here. $>>>$

\subsection{Partisan behaviour of governments: Effects of ideology}

Table 7 reports the results of our analyses of the impact of ideology on the budget deficit, obtained by extending the economic baseline model, including the dummy for the Maastricht effect, with explanatory variables capturing ideological conviction of the government. This variable allows us to draw inference on the extent to which governments show partisan behaviour. Since the partisan model focuses on the impact of ideology, it only provides guidance on the significance of our ideology variable; even when the partisan model applies to our dataset, this does not tell us much about the direction of this impact in our model that explains deficits. Although traditionally left-wing parties are associated with big governments (in terms of the share of their budget in a country's GDP), and right wing rulers with smaller governments, this applies to both the level of expenditures (social security, subsidies) and revenues 
(taxes). At the same time, leftist governments can be expected to in favour a Keynesian anti-cyclical policy that, when properly pursued, ensures that the surpluses created during prosperous times should cancel out the deficits built on during worse times. Therefore, in the long run these arguments do not provide us with univocal guidance on the expected sign of the ideology variable.

Theoretically, a rationale for hypothesis that left-wing governments face higher deficits than their counterparts could be given by the argument that expenditures are more flexible as a policy instrument than revenues. This implies that left-wing governments, following their conviction and increasing the size of the government, will in first instance increase expenditures while not being able to cover this increment by a simultaneous increase in revenues. Consequently, in the short run, they build on a deficit. Since often the duration of governments is rather limited in comparison to the lag that comes with a typical tax measure - or, alternatively, the length of the business cycle -, the left-wing governments will not always be in office long enough to be able to cover the increased expenditures by higher revenues later in their term. The reverse argument applies to right-wing governments: the effects of a policy aimed at decreasing the size of the government will first become visible on the expenditures side, whereas the revenues typically respond with a lag. Consequently an improvement in the budgetary position will result.

Despite this rationale, and in line with the lack of more profound theoretical expectations on the direction of a partisan effect, results presented in the empirical literature suggest that government ideology is not a significant determinant of budget deficits. Our findings in the first column of table 7 confirm this notion: in the first place the coefficient of our ideology variable is highly insignificant. Besides, the sign stands in contradiction with the intuition exposed above, since a negative sign implies that deficits tend to be lower, the more the government's conviction can be categorised on the left of the political spectrum.

$<<<$ Insert table 7 about here. $>>>$ 
However, when evaluating the explanatory power of our ideology variable, one should bear in mind that the index we have employed is ordinal; hence we assume and imply that the difference between a left-wing government and a centre-left government is just as big as the difference between a centre-right government and a right-wing government. This is a rather strong assumption, and the model in the second column provides the possibility to evaluate its validity. In this case, dummy variables for each category are included separately. In these regressions neutral governments (the third category) are the base, hence their dummy is not included, and we evaluate whether any of the other categories tend to be associated with higher or lower deficits. The results show that for left-wing and right-wing governments, the effects are insignificant. For left wing governments we find a negative coefficient, and for right-wing governments a slightly positive, but neither value can be distinguished from zero. On the other hand, both centre-left and centre-right governments have a positive coefficient that is also significant, at least at a ten percent level. When taking another ideological category as base for the analysis, results are similar. This finding is quite counterintuitive, and suggests that not ideology itself, but rather ideological dispersion within a government is a determinant of deficits. The notion that the significantly positive coefficient for the second category is larger than the one for the fourth category (whereas the effect for the fifth category is indistinguishable from zero) may account for the negative value of the coefficient on the ideology index.

Although the sample period is considerably longer than the periods under consideration in the major part of existing literature, we find comparably inconclusive results. However, when we consider different subsamples and evaluate the parameter values over time, we can draw different inference on ideology. Again, we fix the time window to 20 years, which allows us to draw comparisons between different periods, while not decreasing the number of data points under consideration per regression too much, such that correlation coefficients are still based on time series of appropriate length. Columns 3-8 of table 7 show the results of these analyses, where the starting points of the sample are 1972, 1982 and 1987, respectively. Especially for the model with only the ideology index as explanatory variable, remarkable differences show up. 
The significance in the later periods sharply increases, and the sign remains negative. Main cause for this effect is an increase in the explanatory power of the fifth category variable, which is negative and turns out to be significant at a 10 percent level in the latter two periods. This indeed confirms that left-wing governments tend to be associated with lower deficits than cabinets with a different colour and hence contradicts with the intuitive expectation exposed before, based on the consideration that effects of policy changes are less directly observable at the revenues side than at the expenditures side. As an explanation for this finding, Mulas-Granados (2003) shows that left-wing governments cut back their expenditures more than other governments in the second half of the 1990s, following the Maastricht Treaty. At the same time the revenues were still higher than those of governments with a different colour, and as a result left wing governments were more successful in reducing their deficits during this period. Although an analysis of the economic variables underlying the deficit is beyond the scope of this paper, as an additional remark we can note here that this effect is only present in the fifth category of our ideology variable, representing strictly left wing governments.

\subsection{Opportunistic Behaviour: Political Cycles and the impact of (in)stability}

In the previous subsection, we evaluated the validity of the partisan model, by considering the role that ideological conviction of the government plays in determining budget deficits. Since evidence on the hypothesis of partisanship is not clear-cut and, when significant, often counter-intuitive, a natural follow-up will be a consideration of the alternative: the opportunistic model, stating that governments tend to use budget deficits as in instrument to please their electorate. According to this view, one should be able to observe higher deficits during election periods or shortly before the governmental elections take place.

In table 8 , results are presented for models that include variables covering the timing of elections that allow us to evaluate the magnitude and explanatory power of such an effect. Results in the first column are based on our basic economic model with a dummy variable included to capture the Maastricht-effect, extended by a dummy for election years. Its coefficient is positive and highly significant: during election years, 
the budget deficits tends to be 0,59 percent of GDP higher than during years without elections. The second equation includes a similar dummy, but this one acquires a value of 1 when there were elections in the year before. Its negative value indicates that in the year following the elections, governments tend to implement a correction. After first increasing the budget deficit during an election year, in the next year governments need to improve on their budgetary situation. However, this negative post-election effect is nearly twice as small as the positive election effect on deficits, which gives an explanation for the observation of gradual increases in the debt levels over the major part of our sample.

The third column in table 8 evaluates whether deficits tend to deviate in the year preceding an election. Since this effect is negative, although insignificant at the same time, it confirms the finding by Mink and De Haan (2005) that incumbent governments do not start their behaviour of 'electioneering' until the election year. Including the three variables in a model at the same time leads to slightly weaker results, in column 4, although the same patterns remain present.

$<<<$ Insert table 8 about here. $>>>$

From the results described above, one can indirectly conclude that countries that generally have unstable governments - and who hence have elections more often are likely to have higher deficits. In the last column, this is shown more delicately by employing a stability index as explanatory variable. Adding the stability index to the model directly reveals its negative impact on the budget deficit. However, its coefficient is insignificant. The stability index does not have a high variability within the countries, and consequently, differences between countries at a certain point in time are generally persistent. Since our model also contains fixed effects, these structural differences are captured by the country-dummies, and consequently the coefficient on the stability index only reflects the non-structural part of the actual impact of stability on deficits. Indeed, when we do not allow for unobserved effects in our model, the stability index turns out to be significantly negative. 


\section{Conclusion}

In this paper we evaluated the explanatory power of a set of economic and political determinants of budget deficits. Although an extensive literature already exists that covers or touches this area in political economics, the estimation methods employed in these contributions do often not respond to the particular demands that a typical dataset from political economy poses. Considering the fact that we are dealing with Time Series Cross-Sectional data, and following the remark by Beck and Katz (1995) that the typical structure of these datasets requires particular attention for the validity of the assumptions underlying the estimation method one employs, we extensively analysed our dataset for various econometric characteristics, and in accordance with the results of these analyses we selected an appropriate estimation method.

When evaluating the entire sample period 1971-2006 for all 15 countries under consideration, we find that the ratification of the Maastricht Treaty led to considerable decreases in the deficits. This effect is quite strong, and stronger than the effects of institutional changes that were introduced later in time. In line with most recent literature on political fragmentation, we find that a simple fragmentation index has weak explanatory power for budget deficits, and none of the categories on which the index is built perform better and determinants. Although the ideology index is not significantly related to deficits over the entire sample, in later periods we find a negative relation that reveals that left-wing governments are associated with lower deficits than governments in other categories. Next to this (limited) partisan behaviour, there is clear evidence that governments behave opportunistically to the extent that deficits are higher in election-years and lower in the following year. Finally, in line with this notion, a situation of stability is linked with lower deficits, although this effect is rather weak and insignificant - particularly instability is often associated with countries over the full sample period, and will hence be captured by fixed effects.

Although our choice to employ a different estimation method did not necessarily lead to indicative differences with existing literature, we believe that the particular 
characteristics of economic and political data sets on budget deficits, and the requirements they pose on the estimation techniques, have not received due attention in the field. In this literature, conclusions on the role that different determinants play have been highly dependent on nuances like the specification of the particular variables, and in this context, selection of an appropriate estimation method is crucial when drawing inference. At the same time, the revealed importance of heterogeneity in the analysis and the significant role that unobserved effects play in our model imply that there still exists a challenge to extend the analyses and estimate models that assess the particular characteristics of individual countries and the interdependencies among them to an even bigger extent, such that differences and correspondences in the process underlying budget deficits, and the role that its determinants play, can be exposed in greater detail.

\section{References}

Adolph, C., Butler, D., Wilson, S., 2005. Like Shoes and Shirt, One Size Does Not Fit All: Evidence on time series cross-section estimators and specifications from Monte Carlo experiments. Paper presented at the $101^{\text {st }}$ annual conference of the American Political Science Association, Washington DC, 1-5 September 2005.

Alesina, A.,Perotti, R., 1995. The Political Economy of Budget Deficits. IMF Staff Papers 42 (1), 1-31.

Alesina, A. Perotti, R., 1996. Budget Deficits and Budget Institutions. NBER WP 5556.

Alesina, A., Roubini, N., 1997. Political Cycles and the Macroeconomy. The MIT Press, Cambridge, MA (US).

Andrikopoulos, A., Loizides, I., Prodromidis, K., 2004. Fiscal Policy and Political Business Cycles in the EU. European Journal of Political Economy 20, 125-152. 
Ballabriga, F, Martinez-Mongay, C., 2005. Sustainability of EU Public Finances. European Economy - Economic Papers. European Commission (DC ECFIN) 225.

Barro, R., 1979. On the Determination of Public Debt. Journal of Political Economy $87,940-971$.

Beck, N., Katz, J., 1995. What to do (and not to do) with Time-Series Cross-Section Data. American Political Science Review 89, (3).

Buiter, W., Corsetti, G. , Roubini, N., 1993. Excessive deficits: Sense and Nonsense in the Treaty of Maastricht. Economic Policy 16, 58-100.

Edin, P., Ohlsson, H., 1994. Political Determinants of Budget Deficits: Coalition Effects versus Minority Effects. European Economic Review 35, 1597-1603.

Franzese, R., 2002. Electoral and Partisan Cycles in Economic Policies and Outcomes. Annual Review of Political Science 5, 369-421.

De Haan, J., Sturm, J., 1994. Political and Institutional Determinants of Fiscal Policy in the European Community. Public Choice 80 (1-2), 157-172.

Im, K., Pesaran, M., Shin, Y., 2003. Testing for Unit Roots in Heterogeneous Panels. Journal of Econometrics 115, 53-74.

Lucas, R., Stokey, N., 1983. Optimal Fiscal and Monetary Policy in an Economy without Capital. Journal of Monetary Economics 55, 55-93.

Mink, M., De Haan, J., 2005. Has the Stability and Growth Pact Impeded Political Budget Cycles in the European Union? CESifo WP 1532 (2).

Mulas-Granados, C., 2003. The Political and Economic Determinants of Budgetary Consolidation in Europe. European Political Economy Review 1 (1), 15-39. 
Parks, R., 1967. Efficient Estimation of a System of Regression Equations when Disturbances are Both Serially and Contemporaneously Correlated. Journal of the American Statistical Association 62, 500-509.

Perotti, R., Kontopoulos, Y., 2002. Fragmented Fiscal Policy. Journal of Public Economics 86, 191-222.

Roubini, N., 1995. The Economics of Fiscal Bondage: The Balanced Budget Amendment and Other Binding Fiscal Rules. Manuscript, Yale University.

Roubini, N., Sachs, J., 1989. Political and Economic Determinants of Budget Deficits in the Industrial Democracies. European Economic Review 33 (5), 903-938.

Volkerink, B., De Haan, J., 2001. Fragmented Government Effects on Fiscal Policy: New Evidence. Public Choice 109 (3-4), 221-242.

Woldendorp, J., Keman, H., Budge, I., 2000. Party Government in 48 Democracies (1945-1998). Kluwer Academic Publishers, Dordrecht (NL).

Wooldridge, Jeffrey M., 2002. Econometric Analysis of Cross Section and Panel Data. The MIT Press, Cambridge, MA. 


\section{Appendix A: Technical Note}

For the calculation of the Panel Corrected Standard Errors, we follow Beck and Katz (1995) and use estimators that will be specified below. For the coefficients of the explanatory variables included in $\mathrm{X}$, the regular OLS estimator will be used:

$$
\hat{\beta}=\left(X^{\prime} X\right)^{-1}\left(X^{\prime} y\right) .
$$

The dimensions of the matrix $X$ are $(N T \times K)$, where $N$ is the number of units, $T$ the number of time periods and $K$ the number of explanatory variables is the model. Furthermore, $X$ and $y$ are created by pooling the respective time series per unit below each other, such that the data are structured as a collection of $N$ time series of length $T$ below each other. When using standard OLS, the Gauss-Markov assumptions underlying this method state that the errors $\varepsilon_{\mathrm{i}, \mathrm{t}}$ are spherical, such that

$$
\varepsilon_{i, t} \sim N(0, \Sigma), \text { with }
$$

$$
\Sigma=\sigma^{2} \times I_{N T}
$$

where $I_{N T}$ is the NT $x N T$ identity matrix and $\sigma^{2}$ the error variance, that is invariant over units and over time. When employing PCSE, in contrast, we allow for heteroscedasticity between the units. Besides, we allow the off-diagonal terms in the variance-covariance matrix to be non-zero, and particularly impose some structure on these terms, such that

$$
\varepsilon_{i, t} \sim N(0, \Omega)
$$

The panel correction refers to the structure that is assumed for the matrix $\Omega$, in which we assume that there are spatial correlations between countries, but no temporal correlations between or within countries. As a result, we have

$$
\Omega=\Sigma \otimes I_{T} \text {, that can be estimated by }
$$

$$
\hat{\Omega}=\hat{\Sigma} \otimes I_{T} .
$$

We should note here that after the calculation of the error terms one can correct for serial correlation in the country-specific series. After taking care of that, we can estimate the respective elements of the (time-invariant) matrix $\Sigma$ by calculating the 
covariances between the estimated errors $e_{i, t}$ obtained by applying OLS between all pairs $(i, j)$ :

(A7)

$$
\hat{\Sigma}_{i, j}=\frac{\sum_{t=1}^{T} e_{i, t} e_{j, t}}{T} .
$$

In matrix notation, this reduces to

$$
\text { (A8) } \quad \hat{\Sigma}=\frac{\left(E^{\prime} E\right)}{T} \text {, }
$$

where $\mathrm{E}$ is the $(T x N)$ matrix of OLS residuals. Finally, as a consequence, the Panel Corrected Standard Errors can be calculated by the formula

$$
\begin{aligned}
& \sqrt{\operatorname{diag}\left\{\left(X^{\prime} X\right)^{-1} X^{\prime} \hat{\Omega} X\left(X^{\prime} X\right)^{-1}\right\}} \\
& \sqrt{\operatorname{diag}\left\{\left(X^{\prime} X\right)^{-1} X^{\prime}\left[\frac{E^{\prime} E}{T} \otimes I_{T}\right] X\left(X^{\prime} X\right)^{-1}\right\}} .
\end{aligned}
$$




\section{Appendix B:}

The sources used for developing the political variables IDEO, POL, ELE, DUR are:

Adam Carr's election archive: http://psephos.adam-carr.net/

The following websites:

- $\quad$ http://electionresources.org/

- https://www.cia.gov/library/publications/the-world-factbook/index.html

- $\quad$ http://www.parties-and-elections.de

Various issues of the Political Data Yearbooks from European Journal of Political Research.

Woldendorp, J., Keman, H., Budge, I., 2000. Party Government in 48 Democracies (1945-1998). Kluwer Academic Publishers, Dordrecht. 


\section{Appendix C: Tables and Figures}

Table 1: Average Budget Balance per country per time period

\begin{tabular}{|c|cccc|cc|}
\hline Year & $1971-1980$ & $1981-1990$ & $1991-2000$ & $2001-2006$ & $1970-1993$ & $1994-2006$ \\
\hline Belgium & $-5,42$ & $-10,12$ & $-3,87$ & $-0,25$ & $-7,61$ & $-1,07$ \\
Denmark & 1,43 & $-1,91$ & $-1,41$ & 2,08 & $-0,72$ & 0,91 \\
Germany & $-2,01$ & $-2,01$ & $-2,30$ & $-3,19$ & $-2,15$ & $-2,55$ \\
Greece & $-1,35$ & $-10,36$ & $-8,24$ & $-5,39$ & $-6,81$ & $-5,69$ \\
Spain & $-0,58$ & $-4,45$ & $-4,10$ & 0,32 & $-2,98$ & $-1,49$ \\
France & $-0,29$ & $-2,38$ & $-3,69$ & $-2,99$ & $-1,89$ & $-3,02$ \\
Ireland & $-7,92$ & $-8,59$ & $-0,15$ & 1,01 & $-7,31$ & 1,25 \\
Italy & $-7,45$ & $-11,22$ & $-6,33$ & $-3,59$ & $-9,48$ & $-3,66$ \\
Luxembourg & 2,33 & 3,15 & 2,44 & 1,21 & 2,47 & 2,27 \\
Netherlands & $-1,49$ & $-4,96$ & $-1,91$ & $-1,14$ & $-3,23$ & $-1,07$ \\
Austria & $-0,87$ & $-3,20$ & $-3,12$ & $-1,00$ & $-2,28$ & $-1,92$ \\
Portugal & $-2,90$ & $-6,46$ & $-4,85$ & $-3,89$ & $-5,01$ & $-3,75$ \\
Finland & 4,93 & 3,98 & $-2,22$ & 3,41 & 2,82 & 1,65 \\
Sweden & 1,69 & $-0,79$ & $-3,54$ & 0,77 & $-0,85$ & $-0,12$ \\
UK & $-3,10$ & $-2,17$ & $-3,09$ & $-2,17$ & $-3,20$ & $-1,64$ \\
\hline EU-15 & 1,53 & 4,10 & 3,09 & 0,99 & 3,22 & 1,33 \\
\hline
\end{tabular}


Table 2: Political fragmentation: Fraction of time spent in each category per country

\begin{tabular}{|c|cccc|}
\hline Fragmentation & 0 & 1 & 2 & 3 \\
\hline Belgium & 0,0 & 2,9 & 97,1 & 0,0 \\
Denmark & 0,0 & 11,4 & 5,7 & 82,9 \\
Germany & 0,0 & 100,0 & 0,0 & 0,0 \\
Greece & 97,1 & 2,9 & 0,0 & 0,0 \\
Spain & 60,0 & 22,9 & 5,7 & 11,4 \\
France & 2,9 & 57,1 & 25,7 & 14,3 \\
Ireland & 14,3 & 74,3 & 2,9 & 8,6 \\
Italy & 0,0 & 11,4 & 62,9 & 25,7 \\
Luxembourg & 0,0 & 100,0 & 0,0 & 0,0 \\
Netherlands & 0,0 & 57,1 & 42,9 & 0,0 \\
Austria & 31,4 & 65,7 & 2,9 & 0,0 \\
Portugal & 37,1 & 34,3 & 17,1 & 11,4 \\
Finland & 0,0 & 2,9 & 94,3 & 2,9 \\
Sweden & 0,0 & 8,6 & 8,6 & 82,9 \\
UK & 97,1 & 0,0 & 2,9 & 0,0 \\
\hline EU-15 & 22,7 & 36,8 & 24,6 & 16,0 \\
\hline
\end{tabular}


Table 3: Fraction of time spent in each ideological category per country

\begin{tabular}{|c|ccccc|}
\hline Ideology & $\mathbf{1}$ & $\mathbf{2}$ & $\mathbf{3}$ & $\mathbf{4}$ & $\mathbf{5}$ \\
\hline Belgium & 21,6 & 2,7 & 75,7 & 0,0 & 0,0 \\
Denmark & 45,9 & 2,7 & 0,0 & 13,5 & 37,8 \\
Germany & 43,2 & 0,0 & 5,4 & 51,4 & 0,0 \\
Greece & 32,4 & 18,9 & 0,0 & 13,5 & 35,1 \\
Spain & 35,1 & 18,9 & 5,4 & 16,2 & 24,3 \\
France & 37,8 & 16,2 & 10,8 & 2,7 & 32,4 \\
Ireland & 54,1 & 35,1 & 10,8 & 0,0 & 0,0 \\
Italy & 16,2 & 62,2 & 8,1 & 13,5 & 0,0 \\
Luxembourg & 21,6 & 21,6 & 56,8 & 0,0 & 0,0 \\
Netherlands & 37,8 & 16,2 & 35,1 & 10,8 & 0,0 \\
Austria & 0,0 & 18,9 & 37,8 & 13,5 & 29,7 \\
Portugal & 32,4 & 16,2 & 16,2 & 21,6 & 13,5 \\
Finland & 0,0 & 10,8 & 75,7 & 13,5 & 0,0 \\
Sweden & 18,9 & 2,7 & 2,7 & 27,0 & 48,6 \\
UK & 51,4 & 2,7 & 2,7 & 21,6 & 21,6 \\
\hline EU-15 & 29,9 & 16,4 & 22,9 & 14,6 & 16,2 \\
\hline
\end{tabular}


Table 4: Average values of the Stability Index

\begin{tabular}{|c|ccccc|}
\hline Stability & $1971-1980$ & $1981-1990$ & $1991-2000$ & $2001-2006$ & $\begin{array}{c}\text { Country- } \\
\text { Average }\end{array}$ \\
\hline Belgium & 0,40 & 0,73 & 0,89 & 0,92 & 0,72 \\
Denmark & 0,42 & 0,54 & 0,60 & 0,57 & 0,53 \\
Germany & 0,70 & 0,84 & 0,92 & 0,68 & 0,80 \\
Greece & 0,54 & 0,83 & 0,77 & 0,85 & 0,73 \\
Spain & 0,77 & 0,79 & 0,89 & 0,85 & 0,82 \\
France & 0,42 & 0,40 & 0,55 & 0,94 & 0,54 \\
Ireland & 0,69 & 0,58 & 0,59 & 0,93 & 0,67 \\
Italy & 0,18 & 0,33 & 0,28 & 0,58 & 0,32 \\
Luxembourg & 1,00 & 1,00 & 0,91 & 0,79 & 0,94 \\
Netherlands & 0,85 & 0,80 & 0,99 & 0,82 & 0,87 \\
Austria & 0,91 & 0,87 & 0,74 & 0,90 & 0,85 \\
Portugal & 0,49 & 0,59 & 0,95 & 0,48 & 0,65 \\
Finland & 0,40 & 0,78 & 0,85 & 0,96 & 0,72 \\
Sweden & 0,61 & 0,55 & 0,69 & 0,95 & 0,67 \\
UK & 0,61 & 0,76 & 0,83 & 0,66 & 0,72 \\
\hline EU-15 & 0,60 & 0,69 & 0,76 & 0,79 & 0,70 \\
\hline
\end{tabular}


Table 5: Basic model

\begin{tabular}{|c|ccc|}
\hline$E q . N r$. & 1 & 2 & 3 \\
\hline \multirow{2}{*}{ Def $\mathrm{t}_{\mathrm{t}}$} & 0,908 & 0,836 & 0,828 \\
& $(39,377)$ & $(28,090)$ & $(28,758)$ \\
$\Delta \mathrm{U}$ & 0,588 & 0,620 & 0,559 \\
& $(6,957)$ & $(7,447)$ & $(6,717)$ \\
DRB & 0,010 & 0,013 & 0,009 \\
& $(0,982)$ & $(1,306)$ & $(0,979)$ \\
\multirow{2}{*}{$\mathrm{g}$} & $-0,127$ & $-0,107$ & $-0,100$ \\
& $(-3,609)$ & $(-3,101)$ & $(-2,974)$ \\
\multirow{2}{*}{$\delta_{\mathrm{M}}$} & & & $-0,514$ \\
& & & $(-2,269)$ \\
\hline \multirow{2}{*}{ Constant } & 0,210 & 0,534 & 0,746 \\
& $(1,629)$ & $(2,153)$ & $(2,867)$ \\
\hline $\mathrm{R}^{2}$ & 0,866 & 0,872 & 0,875 \\
\hline \multirow{2}{*}{ F-test fe [Prob] } & & 1,861 & {$[0,012]$} \\
\hline
\end{tabular}

Parameter values, with t-statistics between parentheses 
Table 6: Effects of Government Fragmentation

\begin{tabular}{|c|c|c|c|c|c|c|}
\hline Period & $\begin{array}{l}1972- \\
2006\end{array}$ & $\begin{array}{l}1972- \\
2006\end{array}$ & $\begin{array}{l}1972- \\
1991\end{array}$ & $\begin{array}{l}1972- \\
1991\end{array}$ & $\begin{array}{l}1982- \\
2001\end{array}$ & $\begin{array}{l}1986- \\
2005\end{array}$ \\
\hline $\operatorname{Def}_{\mathrm{t}-1}$ & $\begin{array}{c}0,826 \\
(28,130)\end{array}$ & $\begin{array}{c}0,825 \\
(27,950)\end{array}$ & $\begin{array}{c}0,794 \\
(16,003)\end{array}$ & $\begin{array}{r}0,789 \\
(15,582)\end{array}$ & $\begin{array}{c}0,787 \\
(18,311)\end{array}$ & $\begin{array}{c}0,787 \\
(17,180)\end{array}$ \\
\hline$\Delta U$ & $\begin{array}{c}0,558 \\
(6,580)\end{array}$ & $\begin{array}{c}0,556 \\
(6,640)\end{array}$ & $\begin{array}{c}0,587 \\
(5,220)\end{array}$ & $\begin{array}{r}0,575 \\
(5,106)\end{array}$ & $\begin{array}{c}0,558 \\
(4,792)\end{array}$ & $\begin{array}{c}0,645 \\
(5,400)\end{array}$ \\
\hline DRB & $\begin{array}{c}0,039 \\
(1,270)\end{array}$ & $\begin{array}{c}0,040 \\
(1,290)\end{array}$ & $\begin{array}{c}0,060 \\
(1,629)\end{array}$ & $\begin{array}{r}0,061 \\
(1,638)\end{array}$ & $\begin{array}{c}0,012 \\
(0,270)\end{array}$ & $\begin{array}{c}-0,012 \\
(-0,290)\end{array}$ \\
\hline$\Delta \mathrm{g}$ & $\begin{array}{c}-0,091 \\
(-2,670)\end{array}$ & $\begin{array}{c}-0,089 \\
(-2,580)\end{array}$ & $\begin{array}{c}-0,090 \\
(-2,241)\end{array}$ & $\begin{array}{r}-0,086 \\
(-2,119)\end{array}$ & $\begin{array}{c}-0,092 \\
(-1,787)\end{array}$ & $\begin{array}{c}-0,109 \\
(-2,020)\end{array}$ \\
\hline$\delta_{M}$ & $\begin{array}{c}-0,494 \\
(-2,150)\end{array}$ & $\begin{array}{c}-0,509 \\
(-2,200)\end{array}$ & - & - & $\begin{array}{c}-0,696 \\
(-2,449)\end{array}$ & $\begin{array}{c}-0,659 \\
(-2,320)\end{array}$ \\
\hline Polfrag & $\begin{array}{c}-0,083 \\
(-0,710)\end{array}$ & & $\begin{array}{c}-0,308 \\
(-1,763)\end{array}$ & & $\begin{array}{c}0,076 \\
(0,543)\end{array}$ & $\begin{array}{c}0,020 \\
(0,150)\end{array}$ \\
\hline Polfrag0 & & $\begin{array}{c}0,230 \\
(0,640)\end{array}$ & & $\begin{array}{r}0,668 \\
(1,248)\end{array}$ & & \\
\hline Polfrag1 & & $\begin{array}{c}0,331 \\
(1,100)\end{array}$ & & $\begin{array}{r}0,662 \\
(1,507)\end{array}$ & & \\
\hline Polfrag2 & & $\begin{array}{c}0,283 \\
(0,920)\end{array}$ & & $\begin{array}{r}0,372 \\
(0,883)\end{array}$ & & \\
\hline C & $\begin{array}{c}0,194 \\
(3,140)\end{array}$ & $\begin{array}{c}0,524 \\
(1,178)\end{array}$ & $\begin{array}{c}0,604 \\
(2,044)\end{array}$ & $\begin{array}{r}-0,063 \\
(-0,100)\end{array}$ & $\begin{array}{c}0,691 \\
(1,898)\end{array}$ & $\begin{array}{c}1,152 \\
(2,773)\end{array}$ \\
\hline$R^{2}$ & 0,875 & 0,875 & 0,892 & 0,891 & 0,885 & 0,875 \\
\hline
\end{tabular}

Parameter values, with t-statistics between parentheses 
Table 7: Effects of Ideology, based on a sample period 1971-2004

\begin{tabular}{|c|c|c|c|c|c|c|c|c|}
\hline$E q$. & 1972- & 1972- & 1972- & 1972- & 1982- & 1982- & 1987- & 1987- \\
\hline$N r$. & 2006 & 2006 & 1991 & 1991 & 2001 & 2001 & 2006 & 2006 \\
\hline & 0,828 & 0,821 & 0,787 & 0,777 & 0,777 & 0,769 & 0,785 & 0,788 \\
\hline \multirow[t]{2}{*}{$\operatorname{Def}_{\mathrm{t}-1}$} & $(28,880)$ & $(28,530)$ & $(15,780)$ & $(15,420)$ & $(18,260)$ & $(18,070)$ & $(16,880)$ & $(17,280)$ \\
\hline & 0,555 & 0,542 & 0,569 & 0,547 & 0,553 & 0,532 & 0,596 & 0,585 \\
\hline \multirow[t]{2}{*}{$\Delta \mathrm{U}$} & $(6,630)$ & $(6,460)$ & $(5,050)$ & $(4,840)$ & $(4,820)$ & $(4,640)$ & $(5,060)$ & $(4,940)$ \\
\hline & 0,038 & 0,042 & 0,059 & 0,063 & 0,010 & 0,007 & $-0,014$ & $-0,011$ \\
\hline \multirow[t]{2}{*}{ DRB } & $(1,240)$ & $(1,360)$ & $(1,590)$ & $(1,700)$ & $(0,230)$ & $(0,180)$ & $(-0,320)$ & $(-0,260)$ \\
\hline & $-0,094$ & $-0,090$ & $-0,086$ & $-0,080$ & $-0,092$ & $-0,091$ & $-0,118$ & $-0,116$ \\
\hline \multirow[t]{2}{*}{$\Delta \mathrm{g}$} & $(-2,780)$ & $(-2,650)$ & $(-2,140)$ & $(-1,980)$ & $(-1,800)$ & $(-1,790)$ & $(-2,120)$ & $(-2,110)$ \\
\hline & $-0,519$ & $-0,636$ & & & $-0,602$ & $-0,712$ & $-0,662$ & $-0,824$ \\
\hline \multirow[t]{2}{*}{$\delta_{M}$} & $(-2,350)$ & $(-2,750)$ & & & $(-2,160)$ & $(-2,500)$ & $(-2,240)$ & $(-2,780)$ \\
\hline & $-0,039$ & & 0,042 & & $-0,146$ & & $-0,119$ & \\
\hline \multirow[t]{2}{*}{ Ideo } & $(-0,800)$ & & $(0,640)$ & & $(-2,100)$ & & $(-1,850)$ & \\
\hline & & 0,066 & & $-0,049$ & & 0,091 & & 0,142 \\
\hline \multirow[t]{2}{*}{ Ideo1 } & & $(0,290)$ & & $(-0,160)$ & & $(0,300)$ & & $(0,440)$ \\
\hline & & 0,440 & & 0,414 & & 0,601 & & 0,368 \\
\hline \multirow[t]{2}{*}{ Ideo2 } & & $(1,820)$ & & $(1,000)$ & & $(1,690)$ & & $(1,410)$ \\
\hline & & 0,429 & & 0,639 & & 0,321 & & 0,452 \\
\hline \multirow[t]{2}{*}{ Ideo4 } & & $(1,710)$ & & $(1,580)$ & & $(0,980)$ & & $(1,410)$ \\
\hline & & $-0,214$ & & $-0,054$ & & $-0,605$ & & $-0,499$ \\
\hline \multirow[t]{2}{*}{ Ideo5 } & & $(-0,790)$ & & $(-0,140)$ & & $(-1,790)$ & & $(-1,360)$ \\
\hline & 1,057 & 1,014 & 1,621 & 1,793 & 1,443 & 1,162 & 1,179 & 0,920 \\
\hline C & $(3,160)$ & $(3,140)$ & $(2,960)$ & $(3,210)$ & $(2,880)$ & $(2,530)$ & $(2,790)$ & $(2,380)$ \\
\hline $\mathrm{R}^{2}$ & 0,875 & 0,878 & 0,891 & 0,893 & 0,886 & 0,890 & 0,872 & 0,876 \\
\hline
\end{tabular}

Parameter values, with t-statistics between parentheses 
Table 8: Opportunistic behaviour and the effect of elections and stability

\begin{tabular}{|c|c|c|c|c|c|c|}
\hline $\begin{array}{l}\text { Sample } \\
\text { period. }\end{array}$ & $1972-2005$ & $\begin{array}{r}1972- \\
2005\end{array}$ & $\begin{array}{l}1972- \\
2005\end{array}$ & $\begin{array}{r}1972- \\
2005\end{array}$ & $\begin{array}{l}1972- \\
2003\end{array}$ & $\begin{array}{l}1972- \\
2003 *\end{array}$ \\
\hline \multirow{3}{*}{$\operatorname{Def}_{t-1}$} & 0,826 & 0,828 & 0,824 & 0,828 & 0,824 & 0,895 \\
\hline & $(28,400)$ & $(28,360)$ & $(28,070)$ & $(28,410)$ & $(26,530)$ & $(36,960)$ \\
\hline & 0,549 & 0,558 & 0,564 & 0,552 & 0,542 & 0,505 \\
\hline \multirow[t]{2}{*}{$\Delta U$} & $(6,510)$ & $(6,630)$ & $(6,640)$ & $(6,540)$ & $(6,070)$ & $(5,630)$ \\
\hline & 0,036 & 0,037 & 0,039 & 0,035 & 0,038 & 0,038 \\
\hline \multirow[t]{2}{*}{ DRB } & $(1,180)$ & $(1,190)$ & $(1,260)$ & $(1,150)$ & $(1,190)$ & $(1,170)$ \\
\hline & $-0,097$ & $-0,093$ & $-0,091$ & $-0,098$ & $-0,090$ & $-0,109$ \\
\hline \multirow[t]{2}{*}{$\Delta g$} & $(-2,870)$ & $(-2,740)$ & $(-2,670)$ & $(-2,900)$ & $(-2,560)$ & $(-3,020)$ \\
\hline & $-0,492$ & $-0,511$ & $-0,512$ & $-0,502$ & $-0,451$ & $-0,384$ \\
\hline \multirow[t]{2}{*}{$\delta_{M}$} & $(-2,180)$ & $(-2,250)$ & $(-2,230)$ & $(-2,230)$ & $(-1,780)$ & $(1,490)$ \\
\hline & 0,575 & & & 0,493 & & \\
\hline \multirow[t]{2}{*}{$\mathrm{Elec}_{\mathrm{t}}$} & $(3,880)$ & & & $(2,900)$ & & \\
\hline & & $-0,312$ & & $-0,180$ & & \\
\hline \multirow[t]{2}{*}{ Elec $_{t-1}$} & & $(-2,060)$ & & $(-1,060)$ & & \\
\hline & & & $-0,193$ & $-0,081$ & & \\
\hline \multirow[t]{2}{*}{ Elec $_{t+1}$} & & & $(-1,260)$ & $(-0,480)$ & & \\
\hline & & & & & $-0,283$ & $-0,504$ \\
\hline \multirow[t]{2}{*}{ Stab } & & & & & $(-0,790)$ & $(-1,850)$ \\
\hline & 0,857 & 1,117 & 1,096 & 0,954 & 1,187 & 0,755 \\
\hline C & $(2,660)$ & $(3,470)$ & $(3,440)$ & $(2,850)$ & $(2,890)$ & $(2,840)$ \\
\hline $\mathrm{R}^{2}$ & 0,878 & 0,876 & 0,865 & 0,879 & 0,875 & 0,868 \\
\hline
\end{tabular}

Parameter values, with t-statistics between parentheses

* No fixed effects are included in this model 
Figure 1: Graphs on Ideology

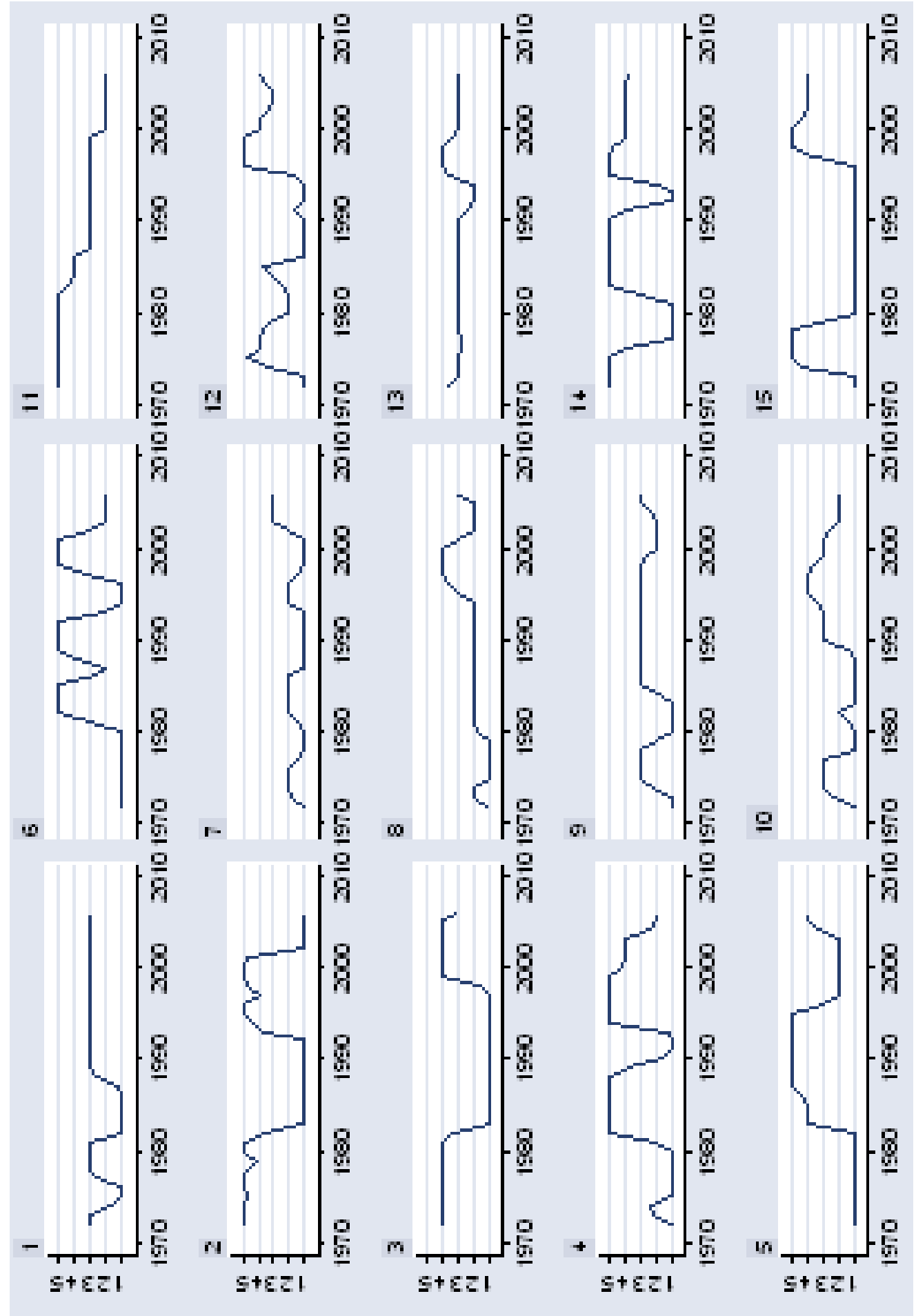

Graphical representation of the development of the ideology index over time. The numbers refer to the following countries: 1: Belgium, 2: Denmark, 3: Germany, 4: Greece, 5: Spain, 6: France, 7: Ireland, 8: Italy, 9: Luxembourg, 10: The Netherlands, 11: Austria, 12: Portugal, 13: Finland, 14: Sweden, 15: UK. 


\section{CESifo Working Paper Series}

for full list see www.cesifo-group.org/wp

(address: Poschingerstr. 5, 81679 Munich, Germany, office@cesifo.de)

2549 Johannes Rincke and Christian Traxler, Deterrence through Word of Mouth, February 2009

2550 Gabriella Legrenzi, Asymmetric and Non-Linear Adjustments in Local Fiscal Policy, February 2009

2551 Bruno S. Frey, David A. Savage and Benno Torgler, Surviving the Titanic Disaster: Economic, Natural and Social Determinants, February 2009

2552 Per Engström, Patrik Hesselius and Bertil Holmlund, Vacancy Referrals, Job Search, and the Duration of Unemployment: A Randomized Experiment, February 2009

2553 Giorgio Bellettini, Carlotta Berti Ceroni and Giovanni Prarolo, Political Persistence, Connections and Economic Growth, February 2009

2554 Steinar Holden and Fredrik Wulfsberg, Wage Rigidity, Institutions, and Inflation, February 2009

2555 Alexander Haupt and Tim Krieger, The Role of Mobility in Tax and Subsidy Competition, February 2009

2556 Harald Badinger and Peter Egger, Estimation of Higher-Order Spatial Autoregressive Panel Data Error Component Models, February 2009

2557 Christian Keuschnigg, Corporate Taxation and the Welfare State, February 2009

2558 Marcel Gérard, Hubert Jayet and Sonia Paty, Tax Interactions among Belgian Municipalities: Does Language Matter?, February 2009

2559 António Afonso and Christophe Rault, Budgetary and External Imbalances Relationship: A Panel Data Diagnostic, February 2009

2560 Stefan Krasa and Mattias Polborn, Political Competition between Differentiated Candidates, February 2009

2561 Carsten Hefeker, Taxation, Corruption and the Exchange Rate Regime, February 2009

2562 Jiahua Che and Gerald Willmann, The Economics of a Multilateral Investment Agreement, February 2009

2563 Scott Alan Carson, Demographic, Residential, and Socioeconomic Effects on the Distribution of $19^{\text {th }}$ Century US White Statures, February 2009

2564 Philipp Harms, Oliver Lorz and Dieter Urban, Offshoring along the Production Chain, February 2009 
2565 Patricia Apps, Ngo Van Long and Ray Rees, Optimal Piecewise Linear Income Taxation, February 2009

2566 John Whalley and Shunming Zhang, On the Arbitrariness of Consumption, February 2009

2567 Marie-Louise Leroux, Endogenous Differential Mortality, Non-Contractible Effort and Non Linear Taxation, March 2009

2568 Joanna Bęza-Bojanowska and Ronald MacDonald, The Behavioural Zloty/Euro Equilibrium Exchange Rate, March 2009

2569 Bart Cockx and Matteo Picchio, Are Short-Lived Jobs Stepping Stones to Long-Lasting Jobs?, March 2009

2570 David Card, Jochen Kluve and Andrea Weber, Active Labor Market Policy Evaluations: A Meta-analysis, March 2009

2571 Frederick van der Ploeg and Anthony J. Venables, Harnessing Windfall Revenues: Optimal Policies for Resource-Rich Developing Economies, March 2009

2572 Ondřej Schneider, Reforming Pensions in Europe: Economic Fundamentals and Political Factors, March 2009

2573 Jo Thori Lind, Karl Ove Moene and Fredrik Willumsen, Opium for the Masses? Conflict-Induced Narcotics Production in Afghanistan, March 2009

2574 Silvia Marchesi, Laura Sabani and Axel Dreher, Agency and Communication in IMF Conditional Lending: Theory and Empirical Evidence, March 2009

2575 Carlo Altavilla and Matteo Ciccarelli, The Effects of Monetary Policy on Unemployment Dynamics under Model Uncertainty - Evidence from the US and the Euro Area, March 2009

2576 Falko Fecht, Kjell G. Nyborg and Jörg Rocholl, The Price of Liquidity: Bank Characteristics and Market Conditions, March 2009

2577 Giorgio Bellettini and Filippo Taddei, Real Estate Prices and the Importance of Bequest Taxation, March 2009

2578 Annette Bergemann and Regina T. Riphahn, Female Labor Supply and Parental Leave Benefits - The Causal Effect of Paying Higher Transfers for a Shorter Period of Time, March 2009

2579 Thomas Eichner and Rüdiger Pethig, EU-Type Carbon Emissions Trade and the Distributional Impact of Overlapping Emissions Taxes, March 2009

2580 Antonios Antypas, Guglielmo Maria Caporale, Nikolaos Kourogenis and Nikitas Pittis, Selectivity, Market Timing and the Morningstar Star-Rating System, March 2009 
2581 António Afonso and Christophe Rault, Bootstrap Panel Granger-Causality between Government Budget and External Deficits for the EU, March 2009

2582 Bernd Süssmuth, Malte Heyne and Wolfgang Maennig, Induced Civic Pride and Integration, March 2009

2583 Martin Peitz and Markus Reisinger, Indirect Taxation in Vertical Oligopoly, March 2009

2584 Petra M. Geraats, Trends in Monetary Policy Transparency, March 2009

2585 Johannes Abeler, Armin Falk, Lorenz Götte and David Huffman, Reference Points and Effort Provision, March 2009

2586 Wolfram F. Richter, Taxing Education in Ramsey’s Tradition, March 2009

2587 Yin-Wong Cheung, Menzie D. Chinn and Eiji Fujii, China's Current Account and Exchange Rate, March 2009

2588 Alexander Haupt and Silke Uebelmesser, Voting on Labour-Market Integration and Education Policy when Citizens Differ in Mobility and Ability, March 2009

2589 Hans Jarle Kind, Marko Koethenbuerger and Guttorm Schjelderup, Should UtilityReducing Media Advertising be Taxed?, March 2009

2590 Alessandro Cigno, How to Avoid a Pension Crisis: A Question of Intelligent System Design, March 2009

2591 Helmut Lütkepohl and Fang Xu, The Role of the Log Transformation in Forecasting Economic Variables, March 2009

2592 Rainald Borck, Hyun-Ju Koh and Michael Pflüger, Inefficient Lock-in and Subsidy Competition, March 2009

2593 Paolo M. Panteghini, On the Equivalence between Labor and Consumption Taxation, March 2009

2594 Bruno S. Frey, Economists in the PITS?, March 2009

2595 Natalie Chen and Dennis Novy, International Trade Integration: A Disaggregated Approach, March 2009

2596 Frédérique Bec and Christian Gollier, Term Structure and Cyclicity of Value-at-Risk: Consequences for the Solvency Capital Requirement, March 2009

2597 Carsten Eckel, International Trade and Retailing, March 2009

2598 Gianni De Nicolò and Iryna Ivaschenko, Global Liquidity, Risk Premiums and Growth Opportunities, March 2009 
2599 Jay Pil Choi and Heiko Gerlach, International Antitrust Enforcement and Multi-Market Contact, March 2009

2600 Massimo Bordignon and Guido Tabellini, Moderating Political Extremism: Single Round vs Runoff Elections under Plurality Rule, April 2009

2601 Ana B. Ania and Andreas Wagener, The Open Method of Coordination (OMC) as an Evolutionary Learning Process, April 2009

2602 Simon Gächter, Daniele Nosenzo, Elke Renner and Martin Sefton, Sequential versus Simultaneous Contributions to Public Goods: Experimental Evidence, April 2009

2603 Philippe Jehiel and Andrew Lilico, Smoking Today and Stopping Tomorrow: A Limited Foresight Perspective, April 2009

2604 Andreas Knabe, Steffen Rätzel, Ronnie Schöb and Joachim Weimann, Dissatisfied with Life, but Having a Good Day: Time-Use and Well-Being of the Unemployed, April 2009

2605 David Bartolini and Raffaella Santolini, Fiscal Rules and the Opportunistic Behaviour of the Incumbent Politician: Evidence from Italian Municipalities, April 2009

2606 Erkki Koskela and Jan König, Can Profit Sharing Lower Flexible Outsourcing? A Note, April 2009

2607 Michel Beine, Frédéric Docquier and Çağlar Özden, Diasporas, April 2009

2608 Gerd Ronning and Hans Schneeweiss, Panel Regression with Random Noise, April 2009

2609 Adam S. Booij, Bernard M.S. van Praag and Gijs van de Kuilen, A Parametric Analysis of Prospect Theory's Functionals for the General Population, April 2009

2610 Jeffrey R. Brown, Julia Lynn Coronado and Don Fullerton, Is Social Security Part of the Social Safety Net?, April 2009

2611 Ali Bayar and Bram Smeets, Economic, Political and Institutional Determinants of Budget Deficits in the European Union, April 2009 